Jelena M. Avramović ${ }^{1}$, Dragana B. Radosavljević ${ }^{2}$, Ana V. Veličković ${ }^{1}$, Ivan J. Stojković ${ }^{3}$, Olivera S. Stamenković ${ }^{1}$, Vlada B. Veljković ${ }^{1 *}$

${ }^{1}$ University of Niš, Faculty of Technology, Leskovac, Serbia

${ }^{2}$ University of Priština, Faculty of Technical Sciences, Kosovska Mitrovica, Serbia, ${ }^{3}$ University of Belgrade, Faculty of Technology and Metallurgy, Belgrade, Serbia
Scientific paper

ISSN 0351-9465, E-ISSN 2466-2585

UDC:665.75.001.572

doi:10.5937/zasmat1901070A

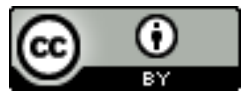

Zastita Materijala $60(1)$

$70-80$ (2019)

\title{
Statistical modeling and optimization of ultrasound-assisted biodiesel production using various experimental designs
}

\begin{abstract}
The present study compares the performances of the regression models developed by the response surface methodology combined with the full factorial, Box-Behnken or face central composite designs applied for the ultrasound-assisted $\mathrm{KOH}$-catalyzed methanolysis of sunflower oil. While all models led to similar optimal reaction conditions, the models based on the simpler designs had the smaller corrected Akaike information criterion values, the insignificant lack of fit and the more favorable statistical criteria than the model based on the full factorial design. Including fewer experiments, the Box-Behnken design can be recommended for the optimization of ultrasound-assisted biodiesel production processes.

Keywords: biodiesel, Box-Behnken design, face central composite design, full factorial design, response surface methodology, ultrasound-assisted transesterification.
\end{abstract}

\section{INTRODUCTION}

In recent years, the design of experiment and the response surface methodology (RSM) are commonly employed in statistical modeling and optimization of many processes in different scientific fields including biodiesel production. This combination results in an empirical model describing esters yield or content as a function the influential process factors on the basis of a minimum number of well-planned experimental runs. Commonly, alcohol-to-oil molar ratio, catalyst amount, temperature and reaction time are considered as influential process factors affecting esters yield although other process factors, specific to a certain biodiesel production method, can also be involved. Different designs of experiments can be employed for collecting the data from the investigated process within the adequately selected ranges of the influential process factors and deriving the model (regression) equation connecting esters yield or content with the process factors. The most frequently used designs of experiments for optimization of ultrasound-assisted biodiesel production from various vegetable oils in the current decade are the full factorial design (FFD) [1-4],

*Corresponding author: Vlada B. Veljković

E-mail: veljkovicvb@yahoo.com

Paper received: 01. 11. 2018.

Paper accepted: 09. 01. 2019.

Paper is available on the website: www.idk.org.rs/journal the Box-Behnken design (BBD) $[5,6]$ and the central composite design (CCD) $[7,8]$. Each of them has its inherent advantages and drawbacks. FFD requires the largest number of experimental runs, thus resulting in a more reliable regression model in the selected experimental cubic space but larger costs, more work and longer time for conducting. Being a part of an FFD experimental cubic space, BBD and face CCD (FCCD) involve a smaller number of experiments but their experimental points are suited at different places (Fig. 1).

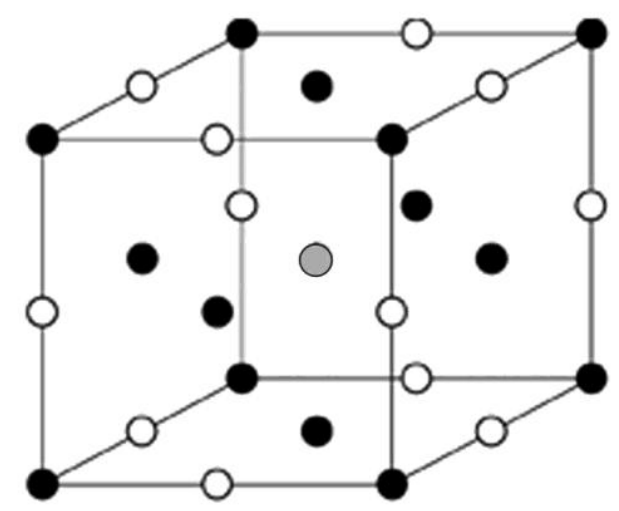

Figure 1. Experimental cubic space (FFD - all points, $B B D$ - white points plus central gray point and FCCD - black points plus central gray point)

Slika 1. Eksperimentalni kubni prostor (FFD - sve tačke, $B B D$ - bele tačke plus centralna siva tačka i FCCD - crne tačke plus centralna siva tačka) 
BBD does not include the vertices of this cubic space while FCCD examines borderline regions. Hence, BBD has a lower number of experimental points and fewer degrees of freedom than FCCD.

The performances of the models derived by the RSM combined with different experimental designs and used for statistical modeling and optimization of ultrasound-assisted biodiesel production processes have not been compared yet. This comparison is useful for identifying the most convenient experimental design with respect to complexity, accuracy and validity of the developed regression model, acceptability of the suggested optimal reaction conditions as well as the economics and efficiency of the required laboratory work. So far, FFD and BBD have been compared in the case of the biodiesel production from sunflower oil without ultrasonication [9]. In addition, Veljković et al. [10] have recently shown that the simpler BBD and FCCD can be used successfully for statistical modeling and optimization of the $\mathrm{NaOH}$-catalyzed sunflower oil ethanolysis instead of the more laborious and expensive FFD.

The present study deals with the performances of the models for fatty acid methyl esters (FAME) content developed by the RSM combined with the three-factor-three level FFD, BBD and FCCD applied for the $\mathrm{KOH}$-catalyzed methanolysis of sunflower oil performed in a batch ultrasonic reactor. The developed models were used for connecting the influential process factors (temperature, methanol-to-oil molar ratio, MOMR, and catalyst loading) with FAME content, asses- sing their statistical significance and optimizing the reaction conditions. The main goal was to test if the more complex FFD could successfully be substituted by the simpler BBD or FCCD.

\section{MATERIALS AND METHODS}

\subsection{Materials, ultrasonic reactor, reaction procedure and analysis}

The applied materials, ultrasonic reactor, reaction procedure and analytical methods can be found elsewhere [11]. The $\mathrm{KOH}$-catalyzed sunflower oil methanolysis was performed in a batch ultrasonic reactor at temperature of $20^{\circ} \mathrm{C}, 30^{\circ} \mathrm{C}$ or $40{ }^{\circ} \mathrm{C}$, MOMR of $4.5: 1,6: 1$ or $7.5: 1$ and $\mathrm{KOH}$ amount of $0.3 \%, 0.5 \%$ or $0.7 \%$ (based on the oil weight) in accordance with the $3^{3}$ FFD with repetition (54 observations in total) [11]. The composition of the reaction mixture samples was determined using HPLC chromatography (Agilent 1100 Series) with a mean relative standard error in the replicates of $\pm 0.8 \%$.

\subsection{Experimental designs, ANOVA and multiple non-linear regression}

The temperature, MOMR and catalyst amount were selected for optimizing FAME content in the ester phase after the $60 \mathrm{~min}$ of reaction. The complete design matrices of the BBD and FCCD are shown in Tables 1 and 2, consisted of 14 and 16 experimental runs, respectively which were the parts of the corresponding FFD [11].

Table 1. Experimental matrix of the BBD with the FAME content predicted on the basis of the reduced linear model

Tabela 1. Eksperimentalna matrica Boks-Benken-ovog plana za sadržaj metal estara predviđenim na osnovu redukovanog linearnog modela

\begin{tabular}{|c|c|c|c|c|c|c|c|c|c|}
\hline \multirow{3}{*}{ Run } & \multicolumn{3}{|c|}{ Coded factors } & \multicolumn{3}{c|}{ Uncoded factors } & \multicolumn{3}{c|}{ FAME, $Y(\%)$} \\
\cline { 2 - 9 } & $\begin{array}{c}\text { Factor } \\
X_{1}\end{array}$ & $\begin{array}{c}\text { Factor } \\
X_{2}\end{array}$ & $\begin{array}{c}\text { Factor } \\
X_{3}\end{array}$ & $\begin{array}{c}\text { Factor } \\
X_{1}\end{array}$ & $\begin{array}{c}\text { Factor } \\
X_{2}\end{array}$ & $\begin{array}{c}\text { Factor } \\
X_{3}\end{array}$ & \multirow{2}{*}{ Actual $^{\mathrm{a}}$} & Predicted $^{\text {Relative }}$ & $\begin{array}{c}\text { Reviation } \\
\text { ( } \%)\end{array}$ \\
\hline 1 & -1 & -1 & 0 & 20 & 4.5 & 0.5 & 49.5 & 54.1 & -9.3 \\
\hline 2 & 1 & -1 & 0 & 40 & 4.5 & 0.5 & 76.3 & 73.0 & 4.4 \\
\hline 3 & -1 & 1 & 0 & 20 & 7.5 & 0.5 & 73.0 & 54.1 & 25.9 \\
\hline 4 & 1 & 1 & 0 & 40 & 7.5 & 0.5 & 79.5 & 73.0 & 8.2 \\
\hline 5 & -1 & 0 & -1 & 20 & 6.0 & 0.3 & 23.1 & 34.9 & -51.2 \\
\hline 6 & 1 & 0 & -1 & 40 & 6.0 & 0.3 & 57.7 & 53.7 & 6.9 \\
\hline 7 & -1 & 0 & 1 & 20 & 6.0 & 0.7 & 72.3 & 73.3 & -1.4 \\
\hline 8 & 1 & 0 & 1 & 40 & 6.0 & 0.7 & 79.8 & 92.2 & -15.5 \\
\hline 9 & 0 & -1 & -1 & 30 & 4.5 & 0.3 & 42.6 & 44.3 & -4.1 \\
\hline 10 & 0 & 1 & -1 & 30 & 7.5 & 0.3 & 38.7 & 44.3 & -14.6 \\
\hline 11 & 0 & -1 & 1 & 30 & 4.5 & 0.7 & 82.8 & 82.7 & 0.1 \\
\hline 12 & 0 & 1 & 1 & 30 & 7.5 & 0.7 & 80.8 & 82.7 & -2.4 \\
\hline 13 & 0 & 0 & 0 & 30 & 6.0 & 0.5 & 73.7 & 63.5 & 13.8 \\
\hline 14 & 0 & 0 & 0 & 30 & 6.0 & 0.5 & 59.7 & 63.5 & -6.5 \\
\hline & & & & & & & \multicolumn{2}{c|}{ MRPD $^{\mathrm{c}}(\%)=$} & \pm 11.7 \\
\hline
\end{tabular}

${ }^{\mathrm{a}}$ Mean value of two replicates [10], ${ }^{\mathrm{b}}$ Relative deviation (\%) $=$ (Actual - Predicted) 100/Actual

${ }^{\mathrm{c}} \mathrm{MPRD}=\sum \mid$ Relative deviation $\mid \mathrm{n}$, where $\mathrm{n}=14$. 
According to the Shapiro-Wilke normality test, the FAME content data were normally distributed at the 0.05 level of significance. The multiple nonlinear regression was used to develop the relationship of FAME content $(Y)$ with the independent variables $\left(X_{1}, X_{2}\right.$ and $X_{3}$, i.e. temperature, MOMR and $\mathrm{KOH}$ amount, respectively) in the form of the second-order polynomial (quadratic) equation (eq. 1):

Table 2. Experimental matrix of the FCCD with the FAME content predicted on the basis of the linear model

Tabela 2. Eksperimentalna matrica centralnog kompozitnog plana za sadržaj metal estara predviđenim na osnovu linearnog modela

\begin{tabular}{|c|c|c|c|c|c|c|c|c|c|}
\hline \multirow[b]{2}{*}{ Run } & \multicolumn{3}{|c|}{ Coded factors } & \multicolumn{3}{|c|}{ Uncoded factors } & \multicolumn{3}{|c|}{ FAME, $Y(\%)$} \\
\hline & $\begin{array}{c}\text { Factor } \\
X_{1}\end{array}$ & $\begin{array}{c}\text { Factor } \\
X_{2}\end{array}$ & $\begin{array}{c}\text { Factor } \\
X_{3}\end{array}$ & $\begin{array}{c}\text { Factor } \\
X_{1}\end{array}$ & $\begin{array}{c}\text { Factor } \\
X_{2}\end{array}$ & $\begin{array}{c}\text { Factor } \\
X_{3}\end{array}$ & Actual $^{a}$ & Predicted & $\begin{array}{c}\text { Relative } \\
\text { deviation } \\
(\%)\end{array}$ \\
\hline 1 & -1 & -1 & -1 & 20 & 4.5 & 0.3 & 30.2 & 27.9 & 7.5 \\
\hline 2 & 1 & -1 & -1 & 40 & 4.5 & 0.3 & 43.2 & 48.0 & \begin{tabular}{|c|}
-11.1 \\
\end{tabular} \\
\hline 3 & -1 & 1 & -1 & 20 & 7.5 & 0.3 & 43.1 & 44.9 & -4.2 \\
\hline 4 & 1 & 1 & -1 & 40 & 7.5 & 0.3 & 71.8 & 65.0 & 9.5 \\
\hline 5 & -1 & -1 & 1 & 20 & 4.5 & 0.7 & 52.1 & 58.5 & -12.3 \\
\hline 6 & 1 & -1 & 1 & 40 & 4.5 & 0.7 & 70.9 & 78.6 & -10.8 \\
\hline 7 & -1 & 1 & 1 & 20 & 7.5 & 0.7 & 81.7 & 75.5 & 7.6 \\
\hline 8 & 1 & 1 & 1 & 40 & 7.5 & 0.7 & 87.9 & 95.5 & -8.7 \\
\hline 9 & -1 & 0 & 0 & 20 & 6 & 0.5 & 35.1 & 51.7 & -47.3 \\
\hline 10 & 1 & 0 & 0 & 40 & 6 & 0.5 & 68.6 & 71.8 & $\begin{array}{l}-4.6 \\
\end{array}$ \\
\hline 11 & 0 & -1 & 0 & 30 & 4.5 & 0.5 & 71.2 & 53.2 & 25.2 \\
\hline 12 & 0 & 1 & 0 & 30 & 7.5 & 0.5 & 68.0 & 70.2 & -3.3 \\
\hline 13 & 0 & 0 & -1 & 30 & 6 & 0.3 & 41.0 & 46.4 & -13.3 \\
\hline 14 & 0 & 0 & 1 & 30 & 6 & 0.7 & 89.6 & 77.0 & 14.0 \\
\hline 15 & 0 & 0 & 0 & 30 & 6 & 0.5 & 73.7 & 61.7 & 16.2 \\
\hline \multirow[t]{2}{*}{16} & 0 & 0 & 0 & 30 & 6 & 0.5 & 59.7 & 61.7 & $\begin{array}{l}-3.4 \\
\end{array}$ \\
\hline & & & & & & & \multicolumn{2}{|r|}{$(\%)=$} & \pm 12.4 \\
\hline
\end{tabular}

${ }^{\mathrm{a}}$ Mean value of two replicates [10], ${ }^{\mathrm{b}}$ Relative deviation (\%) $=$ (Actual - Predicted) 100/Actual.

${ }^{\mathrm{c}} \mathrm{MPRD}=\sum \mid$ Relative deviation $\mid \mathrm{n}$, where $\mathrm{n}=14$.

\subsection{Comparison of the developed model}

The corrected Akaike information criterion (AICc) was used for the selection of the best model among the models with different numbers of parameters $(n / K<40$, where $n$ is the data sample size and $K$ is the number of parameters) [13] (eq. 2):

$$
A I C C=A I C+\frac{2 K(K+1)}{n-K-1}
$$

where $A I C$ denotes the original Akaike information criterion that is related to the residual sum of squares from the fitted model ( RSS ) as follows (eq. 3)

$$
A I C=n \log \left(\frac{R S S}{n}\right)+2 K
$$

$$
\begin{aligned}
& Y=b_{0}+b_{1} X_{1}+b_{2} X_{2}+b_{3} X_{3}+b_{12} X_{1} X_{2}+ \\
& +b_{13} X_{1} X_{3}+b_{23} X_{2} X_{3}+b_{11} X_{1}^{2}+b_{22} X_{2}^{2}+b_{33} X_{3}^{2}
\end{aligned}
$$

where $b_{0}, b_{i}, b_{i i \cdot}$, and $b_{i j}$ are the regression coefficients $(i, j,=1,2,3)$. The fit of the model equation was evaluated by the ANOVA revealing the statistically significant process factors with a confidence level of $95 \%$ ( $p$-value < 0.05). The statistical assessment and the multiple non-linear regression was done by the R-Project software [12]. 
Table 3. Results of sequential model sum of squares test

Tabela 3. Rezultati sekvencijalnog testiranja sume kvadrata

\begin{tabular}{|c|c|c|c|c|c|c|c|}
\hline DoE & Source & Sum of squares & $d f$ & Mean square & F-value & p-value & Remark \\
\hline \multirow{7}{*}{ BBD } & Mean vs Total & 56515.0 & 1 & 56515.0 & & & \\
\hline & Linear vs Mean & 3713.8 & 3 & 1237.9 & 14.7 & $<0.001$ & Suggested \\
\hline & 2FI vs Linear & 287.5 & 3 & 95.8 & 1.2 & 0.375 & \\
\hline & Quadratic vs 2FI & 300.1 & 3 & 100.0 & 1.6 & 0.329 & \\
\hline & Cubic vs Quadratic & 157.7 & 3 & 52.6 & 0.5 & 0.735 & Aliased \\
\hline & Residual & 98.0 & 1 & 98.0 & & & \\
\hline & Total & 61072.1 & 14 & 4362.3 & & & \\
\hline \multirow{7}{*}{ FCCD } & Mean vs Total & 60984.3 & 1 & 60984.3 & & & \\
\hline & Linear vs Mean & 4062.6 & 3 & 1354.2 & 13.3 & $<0.001$ & Suggested \\
\hline & 2FI vs Linear & 39.3 & 3 & 13.1 & 0.1 & 0.9582 & \\
\hline & Quadratic vs 2FI & 402.3 & 3 & 134.1 & 1.0 & 0.4438 & \\
\hline & Cubic vs Quadratic & 670.8 & 4 & 167.7 & 3.0 & 0.2631 & Aliased \\
\hline & Residual & 110.6 & 2 & 55.3 & & & \\
\hline & Total & 66270.0 & 16 & 4141.9 & & & \\
\hline
\end{tabular}

Table 4. Results of lack of fit test

Tabela 4. Rezultati testiranja odstupanja od modela

\begin{tabular}{|c|c|c|c|c|c|c|c|}
\hline DoE & Source & Sum of squares & $\mathrm{df}$ & Mean square & $F$-value & $p$-value & Remark \\
\hline BBD & Linear & 745.3 & 9 & 82.8 & 0.8 & 0.695 & Suggested \\
\hline & $2 \mathrm{FI}$ & 457.7 & 6 & 76.3 & 0.8 & 0.700 & \\
\hline & Quadratic & 157.7 & 3 & 52.6 & 0.5 & 0.735 & \\
\hline & Cubic & 0.0 & 0 & & & & Aliased \\
\hline & Pure Error & 98.0 & 1 & 98.0 & & & \\
\hline FCCD & Linear & 1125.1 & 11 & 102.3 & 1.0 & 0.651 & Suggested \\
\hline & 2FI & 1085.7 & 8 & 135.7 & 1.4 & 0.580 & \\
\hline & Quadratic & 683.4 & 5 & 136.7 & 1.4 & 0.564 & \\
\hline & Cubic & 12.6 & 1 & 12.6 & 0.1 & 0.781 & Aliased \\
\hline & Pure Error & 98.0 & 1 & 98.0 & & & \\
\hline
\end{tabular}

Table 5. Results of model summary statistics test

Tabela 5. Rezultati sumarnog statističkog testiranja modela

\begin{tabular}{|c|l|c|c|c|c|c|c|}
\hline & Source & Stand. dev. & $R^{2}$ & $R_{\text {adj }}^{2}$ & $R_{\text {pred }}^{2}$ & PRESS & \\
\hline BBD & Linear & 9.2 & 0.815 & 0.759 & 0.624 & 1711.9 & Suggested \\
\hline & 2FI & 8.9 & 0.878 & 0.774 & 0.447 & 2520.0 & \\
\hline & Quadratic & 8.0 & 0.944 & 0.818 & 0.360 & 2914.4 & \\
\hline & Cubic & 9.9 & 0.978 & 0.720 & & $-^{\mathrm{a}}$ & Aliased \\
\hline FCCD & Linear & 10.1 & 0.769 & 0.711 & 0.624 & 1985.6 & Suggested \\
\hline & FFI & 11.5 & 0.776 & 0.627 & 0.106 & 4725.6 & \\
\hline & Quadratic & 11.4 & 0.852 & 0.630 & -0.403 & 7417.2 & \\
\hline & Cubic & 7.4 & 0.979 & 0.843 & -3.670 & 24686.4 & Aliased \\
\hline
\end{tabular}

${ }^{\mathrm{a}}$ Cases with leverage of 1.0: PRESS statistic not defined. 
Excluding the aliased cubic models, the quadratic models had the highest $R^{2}$-values among the models. However, for the quadratic BBD-based model, the $R_{\text {pred }}^{2}$-value of 0.360 was not as close to the $R_{a d j}^{2}$-value of 0.818 as one might normally expect, i.e. the difference between them was larger than the recommended value of 0.2 . This indicated a possible problem with the developed model and/or data, so outliers, response transformation or model reduction should be considered. On the other side, the quadratic FCCD-based model had a negative $R_{\text {pred }}^{2}$-value, which meant that the overall mean was a better predictor of FAME content than this model. As compromised, the quadratic models were disregarded. Therefore, the simpler linear models were further considered by the ANOVA (Table 6). The $F_{\text {moder }}$ and $p$-values implied the models were significant, meaning that the two models fit well. The $R^{2}$-values implied the acceptable goodness of fit of both linear models while the $R_{\text {pred }}^{2}$-values were in reasonable agreement with the $R_{\text {adj }}^{2}$-values. The same conclusion was supported by the relatively low MRPD-values (BBD: $\pm 11.9 \%, 14$ data; and FCCD: $\pm 12.4 \%, 16$ data). Finally, there was no outlier in the BBD and FCCD datasets.

Table 6. ANOVA results for the BBD- and FCCD linear models

Tabela 6. Rezultati ANOVA za linearne modele Boks-Benken-ovog i centralnog kompozitnog plana

\begin{tabular}{|c|c|c|c|c|c|c|c|}
\hline DoE & Model equation & Source & Sum of squares & $\mathrm{df}$ & Mean square & $F$-value & $p$-value \\
\hline \multirow{15}{*}{ BBD } & \multirow{8}{*}{ Linear } & Model & 3713.8 & 3 & 1237.9 & 14.7 & $<0.001$ \\
\hline & & $X_{1}$ & 710.6 & 1 & 710.6 & 8.4 & 0.016 \\
\hline & & $X_{2}$ & 54.1 & 1 & 54.1 & 0.6 & 0.442 \\
\hline & & $X_{3}$ & 2949.1 & 1 & 2949.1 & 35.0 & $<0.001$ \\
\hline & & Residual & 843.3 & 10 & 84.3 & & \\
\hline & & Lack of Fit & 745.3 & 9 & 82.8 & 0.8 & 0.695 \\
\hline & & Pure Error & 98.0 & 1 & 98.0 & & \\
\hline & & Corrected Total & 4557.1 & 13 & & & \\
\hline & \multirow{7}{*}{ Reduced linear } & Model & 3659.8 & 2 & 1829.9 & 22.4 & 0.0001 \\
\hline & & $X_{1}$ & 710.6 & 1 & 710.6 & 8.7 & 0.013 \\
\hline & & $X_{3}$ & 2949.1 & 1 & 2949.1 & 36.2 & $<0.0001$ \\
\hline & & Residual & 897.3 & 11 & 81.6 & & \\
\hline & & Lack of Fit & 799.3 & 10 & 79.9 & 0.8 & 0.706 \\
\hline & & Pure Error & 98.0 & 1 & 98.0 & & \\
\hline & & Corrected Total & 4557.1 & 13 & & & \\
\hline \multirow{8}{*}{ FCCD } & \multirow{8}{*}{ Linear } & Model & 4062.6 & 3 & 1354.2 & 13.3 & $<0.001$ \\
\hline & & $X_{1}$ & 1004.0 & 1 & 1004.0 & 9.9 & 0.009 \\
\hline & & $X_{2}$ & 720.8 & 1 & 720.8 & 7.1 & 0.021 \\
\hline & & $X_{3}$ & 2337.8 & 1 & 2337.8 & 22.9 & $<0.001$ \\
\hline & & Residual & 1223.1 & 12 & 101.9 & & \\
\hline & & Lack of Fit & 1125.1 & 11 & 102.3 & 1.0 & 0.651 \\
\hline & & Pure Error & 98.0 & 1 & 98.0 & & \\
\hline & & Corrected Total & 5285.7 & 15 & & & \\
\hline
\end{tabular}

In the case of the BBD-based linear model, the temperature $\left(X_{1}\right)$ and the catalyst amount $\left(X_{3}\right)$ were only significant model terms while the effect of $\operatorname{MOMR}\left(X_{2}\right)$ on FAME content was insignificant with the confidence level of $95 \%$. According to the FCCD-based linear model, all three process factors had an influential impact on FAME content. As it can be seen from the model equations given in Table 7 , all three linear regression coefficients of the model equations based on the coded factors
(Eqs. T2 and T5) were positive, indicating the positive influence of temperature, MOMR and catalyst amount on FAME content, which was attributed to their accelerating effect on the reaction rate. According to the values of the linear regression coefficients, the catalyst amount $\left(X_{3}\right)$ had higher $F$-value and hence, more significant impact on FAME content than the temperature, while the influence of the MOMR was the least significant. The same conclusion was made from the FFD-based model (Eq. T8, Table 7). 
Since the MOMR $\left(X_{2}\right)$ was a statistically insignificant factor, the BBD-based linear model, (Eqs. T1 and T2) could be simplified by removing it into a reduced linear model (Eqs. T3 and T4 in terms of coded and actual factors, respectively). On the basis of the ANOVA for this model, it was concluded that the model was significant with only a $0.01 \%$ chance that it could occur due to noise while its lack of fit $(p=0.706)$ was insignificant. The $R^{2}$ - value (0.803) demonstrated its good fitting capability which was supported by an acceptable MRPD-value $( \pm 11.7 \%, 14$ data). In addition, the $R_{a d j}^{2}$ - and $R_{\text {pred }}^{2}$-values $(0.767$ and 0.663 , respectively) were high and within 0.2 of each other, implying that the reduced linear model represented the experimental data well.

\section{Table 7. Model equations based on BBD, FCCD and FFD datasets}

Tabela 7. Jednačine modela zasnovane na skupovima podataka Boks-Benken-ovog centralnog kompozitnog i punog faktorijalnog plana

\begin{tabular}{|c|c|c|c|c|}
\hline DoE & Model & Levels & Equation $^{\mathrm{a}}$ & Numeration \\
\hline \multirow{4}{*}{ BBD } & \multirow{2}{*}{ Linear } & Coded & $Y=63.54+9.43 X_{1}+2.60 X_{2}+19.20 X_{3}$ & $\mathrm{~T} 1$ \\
\hline & & Actual & $Y=-23.14+0.94 X_{1}+1.73 X_{2}+96.00 X_{3}$ & T2 \\
\hline & \multirow{2}{*}{ Reduced linear } & Coded & $Y=63.54+9.43 X_{1}+19.20 X_{3}$ & T3 \\
\hline & & Actual & $Y=-12.74+0.94 X_{1}+96.00 X_{3}$ & T4 \\
\hline \multirow{2}{*}{ FCCD } & \multirow{2}{*}{ Linear } & Coded & $Y=61.74+10.02 X_{1}+8.49 X_{2}+15.29 X_{3}$ & T5 \\
\hline & & Actual & $Y=-40.51+1.00 X_{1}+5.66 X_{2}+76.45 X_{3}$ & T6 \\
\hline \multirow{4}{*}{$\mathrm{FDD}^{\mathrm{b}}$} & \multirow{2}{*}{ Reduced cubic } & Coded & $\begin{array}{l}Y=65.01+9.76 \cdot X_{1}+5.86 \cdot X_{2}+17.4 X_{3}- \\
-1.44 \cdot X_{1} X_{2}-3.67 \cdot X_{1} X_{3}+0.60 \cdot X_{2} X_{3}- \\
-3.73 \cdot X_{1}^{2}+4.18 \cdot X_{2}^{2}-4.80 \cdot X_{3}^{2}-3.54 \cdot X_{1} X_{2} X_{3}\end{array}$ & $\mathrm{T7}$ \\
\hline & & Actual & $\begin{array}{l}Y=40.40+1.17 \cdot X_{1}-34.17 \cdot X_{2}+36.21 X_{3}+ \\
+0.494 \cdot X_{1} X_{2}+5.24 \cdot X_{1} X_{3}+37.34 \cdot X_{2} X_{3}- \\
-0.373 \cdot X_{1}^{2}+1.86 \cdot X_{2}^{2}-120.0 \cdot X_{3}^{2}-1.179 \cdot X_{1} X_{2} X_{3}\end{array}$ & T8 \\
\hline & \multirow{2}{*}{ Linear } & Coded & $Y=62.12+9.76 \cdot X_{1}+5.86 \cdot X_{2}+17.04 \cdot X_{3}$ & T9 \\
\hline & & Actual & $Y=-33.19+0.98 \cdot X_{1}+3.91 \cdot X_{2}+85.18 \cdot X_{3}$ & T10 \\
\hline
\end{tabular}

${ }^{\mathrm{a}} X_{1}$ - temperature, $X_{2}-$ MOMR and $X_{3}$ - catalyst amount; and $Y$ - FAME content (\%), ${ }^{\mathrm{b}}$ Taken from Avramović et al. [10]

\subsection{Verification of the $B B D$ - and $F C C D$ - based models}

The developed models were validated on the basis of the corresponding sub-datasets taken from the FFD dataset [11] that were not included in their development. For the BBD-based model, the MRPD for the sub-dataset corresponding to the eight combinations of the extreme levels of the three process factors (i.e. at the vertices of the cube) was about $\pm 22.5 \%$ (16 data; Table 8 ) while its value for the rest of data corresponding to the six combinations of the two process factors at the middle level and one process factors at either low or high level was $\pm 16.2 \%$ (12 data; Table 9 ).

These percentages were higher than those obtained for the data used in the derivation of the two models. Hence, they demonstrated a moderate fitness capability of the two models for the levels of the process factors that were out of the experimental region employed in deriving the models. For the BBD-based reduced linear model, this was ascribed to the fact that the BBD did not examine borderline regions of the employed experimental domain, i.e. the extreme factor combinations. The deviation of the FCCD-based linear model from the experiment was difficult to understand as the used sub-dataset was inside the investigated cubic space including the vortices.

For the FCCD-based model, the MRPD for the sub-dataset corresponding to the twelve combinations of one process factors at the middle level and two process factors at either low or high level was about $\pm 22.4 \%$ (24 data; Table 10 ). 
Table 8. Verification of the BBD reduced linear model on the basis of the FFD data corresponding to the combinations of the extreme levels of the process factors out of the experimental region employed in its development

Tabela 8. Verifikacija redukovanog linearnog BBD modela na osnovu podataka FFD plana koji odgovaraju kombinacijama ekstremnih nivoa procesnih faktora izvan eksperimentalnog regiona koji je korišćen u njegovom razvoju

\begin{tabular}{|c|c|c|c|c|c|}
\hline \multicolumn{3}{|c|}{ Coded factors } & \multicolumn{3}{|c|}{ FAME content, Y (\%) } \\
\hline Factor $X_{1}$ & Factor $X_{2}$ & Factor $X_{3}$ & Actual $^{\mathrm{a}}$ & Predicted & Relative deviation (\%) \\
\hline \multirow[t]{2}{*}{-1} & -1 & -1 & 30.7 & \multirow{2}{*}{32.2} & -4.9 \\
\hline & & & 29.7 & & -8.8 \\
\hline \multirow[t]{2}{*}{1} & -1 & -1 & 33.6 & \multirow{2}{*}{51.0} & -51.8 \\
\hline & & & 52.9 & & 3.4 \\
\hline \multirow[t]{2}{*}{-1} & 1 & -1 & 48.1 & \multirow{2}{*}{37.4} & 22.2 \\
\hline & & & 38.0 & & 1.5 \\
\hline \multirow[t]{2}{*}{1} & 1 & -1 & 75.3 & \multirow{2}{*}{56.2} & 25.3 \\
\hline & & & 68.2 & & 17.5 \\
\hline \multirow[t]{2}{*}{-1} & -1 & 1 & 45.2 & \multirow{2}{*}{70.6} & -56.5 \\
\hline & & & 59.1 & & -19.5 \\
\hline \multirow[t]{2}{*}{1} & -1 & 1 & 65.8 & \multirow{2}{*}{89.4} & -35.9 \\
\hline & & & 76.0 & & -17.7 \\
\hline \multirow[t]{2}{*}{-1} & 1 & 1 & 88.0 & \multirow{2}{*}{75.8} & 13.9 \\
\hline & & & 75.5 & & -0.5 \\
\hline \multirow[t]{2}{*}{1} & 1 & 1 & 81.5 & \multirow{2}{*}{94.6} & -16.1 \\
\hline & & & 94.2 & & -0.4 \\
\hline \multicolumn{5}{|c|}{$M R P D(\%)$} & \pm 22.5 \\
\hline
\end{tabular}

${ }^{\mathrm{a}}$ Taken from Avramović et al. [10].

Table 9. Verification of the BBD-based reduced linear model on the basis of the FFD data corresponding to the combinations of the extreme levels of the two process factors at the middle level and one process factors at either low or high level out of the experimental region employed in its development

Tabela 9. Verifikacija redukovanog linearnog BBD modela na osnovu podataka FFD plana koji odgovaraju kombinacijama ekstremnih nivoa dva procesna faktora na srednjem nivou i jednog procesnog faktora na niskom ili visokom nivou izvan eksperimentalnog regiona koji je korišćen u njegovom razvoju

\begin{tabular}{|c|c|c|c|c|c|}
\hline \multicolumn{3}{|c|}{ Coded factors } & \multicolumn{3}{c|}{ FAME content, $Y(\%)$} \\
\hline Factor $X_{1}$ & Factor $X_{2}$ & Factor $X_{3}$ & Actual ${ }^{\mathrm{a}}$ & Predicted & Rel. deviation (\%) \\
\hline 0 & 0 & -1 & 44.2 & 44.3 & -0.1 \\
\hline 0 & -1 & 0 & 37.8 & & -17.0 \\
\hline & & & 63.4 & 63.5 & -0.1 \\
\hline-1 & 0 & 0 & 79.1 & & 19.7 \\
\hline 1 & 0 & 0 & 41.1 & 54.1 & -31.7 \\
\hline & & & 29.1 & & -85.8 \\
\hline 0 & 1 & 0 & 67.5 & 72.9 & -4.9 \\
\hline 0 & & & 71.9 & 63.5 & 11.8 \\
\hline & 0 & 1 & 64.0 & & 0.8 \\
\hline
\end{tabular}

${ }^{a}$ Taken from Avramović et al. [10]. 
Table 10. Verification of the FCCD linear model on the basis of the FFD data out of the experimental region employed in its development

Tabela 10. Verifikacija FCCD linearnog modela na osnovu podataka FFD plana izvan eksperimentalnog regiona koji je korišćen u njegovom razvoju

\begin{tabular}{|c|c|c|c|c|c|}
\hline \multicolumn{3}{|c|}{ Coded factors } & \multicolumn{3}{|c|}{ FAME content, $Y(\%)$} \\
\hline Factor $X_{1}$ & Factor $X_{2}$ & Factor $X_{3}$ & Actual $^{\mathrm{a}}$ & Predicted & Relative deviation (\%) \\
\hline \multirow[t]{2}{*}{0} & -1 & -1 & 47.5 & 37.3 & 21.4 \\
\hline & & & 37.7 & & 0.9 \\
\hline \multirow[t]{2}{*}{-1} & 0 & -1 & 33.9 & 35.8 & -5.7 \\
\hline & & & 12.3 & & -190.7 \\
\hline \multirow[t]{2}{*}{1} & 0 & -1 & 55.3 & 55.8 & -0.9 \\
\hline & & & 60.1 & & 7.1 \\
\hline \multirow[t]{2}{*}{0} & 1 & -1 & 29.2 & 54.3 & -85.8 \\
\hline & & & 48.2 & & -12.7 \\
\hline \multirow[t]{2}{*}{-1} & -1 & 0 & 36.7 & 42.6 & -16.2 \\
\hline & & & 62.3 & & 31.6 \\
\hline \multirow[t]{2}{*}{1} & -1 & 0 & 77.8 & 62.7 & 19.5 \\
\hline & & & 74.7 & & 16.1 \\
\hline \multirow[t]{2}{*}{-1} & 1 & 0 & 67.4 & 59.6 & 11.6 \\
\hline & & & 78.6 & & 24.2 \\
\hline \multirow[t]{2}{*}{1} & 1 & 0 & 75.9 & 79.6 & -4.9 \\
\hline & & & 83.1 & & 4.2 \\
\hline \multirow[t]{2}{*}{0} & -1 & 1 & 76.1 & 67.9 & 10.7 \\
\hline & & & 89.5 & & 24.1 \\
\hline \multirow[t]{2}{*}{-1} & 0 & 1 & 66.9 & 66.4 & 0.8 \\
\hline & & & 77.7 & & 14.6 \\
\hline \multirow[t]{2}{*}{1} & 0 & 1 & 70.9 & 86.4 & -21.9 \\
\hline & & & 88.7 & & 2.5 \\
\hline \multirow[t]{3}{*}{0} & 1 & 1 & 81.0 & 84.9 & -4.8 \\
\hline & & & 80.6 & & -5.3 \\
\hline & & & & $M R P D(\%)$ & \pm 22.4 \\
\hline
\end{tabular}

${ }^{\mathrm{a} T a k e n ~ f r o m ~ A v r a m o v i c ́ ~ e t ~ a l . ~[10] . ~}$

\subsection{Response surface analysis and optimization}

For selecting the optimal reaction conditions using the BBD-based reduced linear and FCCDbased linear models, the optimization criterion was to achieve the maximum FAME content with the process factors constrained to the applied experimental region. For both models, the used software recommended the same optimal values of the temperature of $40{ }^{\circ} \mathrm{C}$ and catalyst loading of $0.7 \%$. Besides these conditions, the FCCD-based linear models defined the MOMRs of 7.5:1 as the optimal one. The predicted FAME content under these reaction conditions on the basis of the BBD and FFD, respectively was $92.2 \%$ and $95.5 \%$ while the experimental FAME content was $79.8 \%$ and $87.9 \%$. The FFD gave the same optimal reaction conditions as the FCCD and the predicted maximum FAME content of 95.0\% [11].

Since the BBD-based reduced linear model was deviated from the experiment to less degree than the FCCD-based linear model in the whole investigated cubic space, only it was further investigated through the response surface analysis. Figure 2 shows the response surface 3D plots for FAME content as a function of temperature and catalyst loading resulted from the BBD-based reduced linear model. It was obvious that the FAME content increased with the increase of both temperature and catalyst loading. 


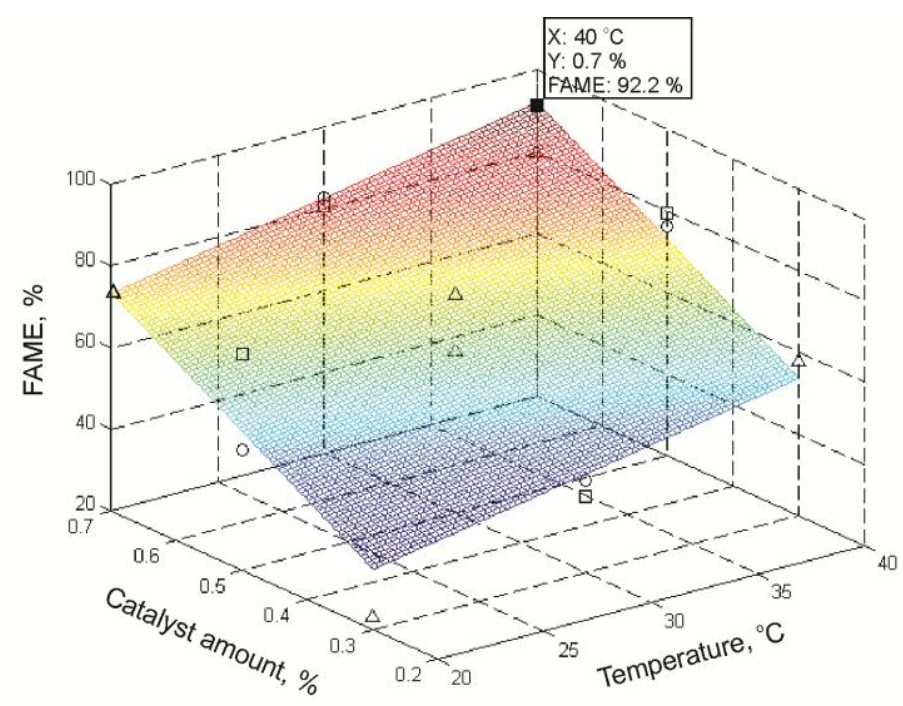

Figure 2. Response surface plot for FAME content as a function of temperature and catalyst loading on the basis of the BBD-based reduced linear model (MOMR: 4.5:1 - $\not, 6: 1-\Delta$ and 7.5:1 - $\gamma$ )

Slika 2. Grafik odzivne površine za sadržaj metal estara kao funkcija temperature i količine katalizatora na bazi redukovanog linearnog modela izvedenog iz Boks-Benken-ovog (MOMR: 4.5: 1 - $\not \subset, 6: 1-\Delta$ i 7.5: 1- r)

3.5. Performance comparison of the BBD-, FCCDand FFD-based models

The performances of the developed models could be compared with respect to their complexity, validity and accuracy, recommended optimal reaction conditions as well as costs and the required laboratory labor [9]. Some comparative criteria are given in Table 11.

Table 11. Comparison of three factor-three-level BBD, FCCD and FFD with replication

Tabela 11. Poređenje Boks-Benken-ovog centralnog kompozitnog i punog faktorijalnog plana

\begin{tabular}{|c|c|c|c|c|c|}
\hline \multirow{3}{*}{ Criterion } & \multicolumn{5}{|c|}{ Experimental design and model equation } \\
\hline & \multicolumn{2}{|c|}{ BBD } & \multirow{2}{*}{$\begin{array}{l}\text { FCCD } \\
\text { Linear }\end{array}$} & \multicolumn{2}{|c|}{ FFD with replication ${ }^{a}$} \\
\hline & Linear & $\begin{array}{l}\text { Reduced } \\
\text { linear }\end{array}$ & & $\begin{array}{l}\text { Reduced } \\
\text { cubic }\end{array}$ & Linear \\
\hline Number of experiments/ regression coefficients & $14 / 4$ & $14 / 3$ & $16 / 4$ & $54 / 11$ & $54 / 4$ \\
\hline $\mathrm{AICc}$ & 114.6 & 110.9 & 130.8 & 429.6 & 421.1 \\
\hline$F_{\text {model-value }}$ & 14.7 & 22.4 & 13.3 & 14.0 & 40.3 \\
\hline$p_{\text {model-value }}$ & 0.0005 & 0.0001 & 0.0004 & $<0.0001$ & $<0.0001$ \\
\hline$R^{2}$ & 0.815 & 0.803 & 0.769 & 0.765 & 0.707 \\
\hline$R_{a d j}^{2}$ & 0.759 & 0.767 & 0.711 & 0.710 & 0.690 \\
\hline$R_{\text {pred }}^{2}$ & 0.624 & 0.663 & 0.624 & 0.623 & 0.659 \\
\hline$p$-lack of fit & 0.695 & 0.472 & 0.651 & 0.028 & 0.021 \\
\hline C.V., \% & 14.5 & 14.2 & 16.4 & 17.4 & 18.0 \\
\hline MRPD, \% & \pm 11.9 & \pm 11.7 & \pm 12.4 & \pm 16.5 & \pm 17.8 \\
\hline \multicolumn{6}{|l|}{ Optimal process conditions: } \\
\hline Temperature $\left(X_{1}\right),{ }^{\circ} \mathrm{C}$ & 40 & 40 & 40 & 32.2 & 40 \\
\hline $\operatorname{MOMR}\left(X_{2}\right), \mathrm{mol} / \mathrm{mol}$ & 6.0 & $4.5-7.5$ & 7.5 & 7.5 & 7.5 \\
\hline Catalyst amount $\left(X_{3}\right), \%$ & 0.7 & 0.7 & 0.7 & 0.7 & 0.7 \\
\hline FAME content, predicted, $\%$ & 92.2 & 92.2 & 95.5 & 88.0 & 95.0 \\
\hline FAME content, actual, \% & $79.8 \pm 8.9$ & $79.8 \pm 8.9$ & $87.9 \pm 6.4$ & $87.9 \pm 0.2^{b}$ & 87.9 \\
\hline
\end{tabular}

${ }^{\mathrm{a}}$ Taken from Avramović et al. [10], ${ }^{\mathrm{b}}$ At $30{ }^{\circ} \mathrm{C}, 7.5: 1$ and $0.7 \%$. 
Measuring the relative quality of a group of models with different numbers of parameters, AICc is a powerful tool for their comparison and selection of the best one among the tested models. Table 11 shows that the BBD- and FCCD-based models have smaller AICc-values than the FFD-based models, as well as the reduced linear BBD-based model has the lowest AICc-value, thus being the "best" one. Also, the BBD- and FCCD-based models are characterized by more favorable statistical criteria like $R^{2}, R_{a d j}^{2}, R_{\text {pred }}^{2}, C . V$. and $M R P D$. Besides that, the BBD and FCCD involve nearly four times smaller number of experiments than the FFD. Furthermore, all models lead to similar optimal reaction conditions. Taking into account all criteria, the BBD can be recommended for the optimization of biodiesel production processes under ultrasonication. Its disadvantage is moderate fitness capability for the levels of the process factors that are out of the experimental region applied in its development. Therefore, this simpler experimental design should be applied with caution under conditions of the extreme factor combinations (borderline regions of the employed experimental domain).

\section{CONCLUSIONS}

The performances of the BBD, FCCD and FFD applied in combination with the RSM for statistical modeling and optimization of the $\mathrm{KOH}$-catalyzed ultrasound-assisted methanolysis of sunflower oil were compared. Besides the statistically insignificant lack of fit, the BBD- and FCCD-based models had smaller AICc-values and more favorable statistical criteria than the FFD-based models. The same optimal temperature and catalyst loading but different MOMR were determined by the models. The BBD was recommended for the optimization of the process conditions as it requires the lowest number of experimental runs, meaning lower costs as well as shorter and less laborious laboratory work.

\section{Acknowledgement}

This work has been funded by the Ministry of Education, Science and Technological Development of the Republic of Serbia (Project III 45001).

\section{REFERENCES}

[1] K.Noipin, S.Kumar (2015) Optimization of ethyl ester production assisted by ultrasonic irradiation, Ultrasonics Sonochemistry, 22, 548-558.

[2] K.M.Rajković, J.M.Avramović, P.S.Milić, O.S. Stamenković, V.B.Veljković (2013) Optimization of ultrasound-assisted base-catalyzed methanolysis of sunflower oil using response surface and artifical neural network methodologies, Chemical Engineering Journal, 215-216, 82-89.

[3] J.Sáez-Bastante, S.Pinzi, G.Arzamendi, M.D.Luque De Castro, F. Priego-Capote, M.P. Dorado (2014a) Influence of vegetable oil fatty acid composition on ultrasound-assisted synthesis of biodiesel, Fuel, 125, 183-191.

[4] J.Sáez-Bastante, S.Pinzi, I.Reyero, F.PriegoCapote, M.D.Luque De Castro, M.P.Dorado (2014b) Biodiesel synthesis from saturated and unsaturated oils assisted by the combination of ultrasound, agitation and heating, Fuel, 131, 6-16.

[5] E.Fayyazi, B.Ghobadian, G.Najafi, B. Hosseinzadeh, R.Mamat, J.Hosseinzadeh (2015) An ultrasound-assisted system for the optimization of biodiesel production from chicken fat oil using a genetic algorithm and response surface methodology, Ultrasonics Sonochemistry, 26, 312320.

[6] O.Khan, M.E. Khan, A.K.Yadav, D.Sharma (2017) The ultrasonic-assisted optimization of biodiesel production from eucalyptus oil, Energy Sources, Part A: Recovery, Utilization and Environmental Effects, 39(13), 1-9.

[7] H.Mootabadi, A.Z.Abdullah (2015) Response surface methodology for simulation of ultrasonicassisted biodiesel production catalyzed by $\mathrm{SrO} / \mathrm{Al}_{2} \mathrm{O}_{3}$ catalyst, Energy Sources, Part A: Recovery, Utilization and Environmental Effects, 37(16), 1747-1755.

[8] M.Mostafaei, B.Ghobadian, M.Barzegar, A. Banakar (2015) Optimization of ultrasonic assisted continuous production of biodiesel using response surface methodology, Ultrasonics Sonochemistry, 27, 54-61.

[9] M.R. Miladinović, O.S. Stamenković, P.T. Banković, A.D.Milutinović-Nikolić, D.M.Jovanović, V.B. Veljković (2016) Modeling and optimization of sunflower oil methanolysis over quicklime bits in a packed bed tubular reactor using the response surface methodology, Energy Conversion and Management, 130, 25-33.

[10] V.B.Veljković, A.V.Veličković, J.M.Avramović, O.S. Stamenković (2018) Modeling of biodiesel production: performance comparison of BoxBehnken, face central composite and full factorial design, Chinise Journal of Chemical Engineering, in press, https://doi.org/10.1016/j.cjche.2018.08.002.

[11] J.M. Avramović, O.S .Stamenković, Z.B. Todorović, M.L. Lazić, V.B. Veljković (2010) Optimization of the ultrasound-assisted base-catalyzed sunflower oil methanolysis by a full factorial design, Fuel Processing Technology, 91, 1551-1557.

[12] http://cran.us.r-project.org

[13] K.Burnham, D. Anderson, K.P.Huyvaert (2011) AIC model selection and multimodel inference in behavioral ecology: some background, observations, and comparisons, Behavioral Ecology and Sociobiology, 65 (1), 23-35. 


\section{IZVOD}

\section{STATISTIČKO MODELOVANJE I OPTIMIZACIJA PROIZVODNJE BIODIZELA U PRISUSTVU ULTRAZVUKA PRIMENOM RAZLIČITIH EKSPERIMENTALNIH PLANOVA}

$U$ radu se porede performanse regresionih modela razvijenih na osnovu kombinovanja metodologije površine odziva sa punim faktorijelnim, Boks-Benken-ovim ili centralnim kompozitnim planom kada se primene na ultrazvukom podržanu bazno-katalizovanu metanolizu suncokretovog ulja. lako su svi modeli dali slične optimalne uslove reakcije, modeli zasnovani na jednostavnijim planovima imali su manje vrednosti Akaike-ovog informacionog kriterijuma, neznačajnu vrednost odstupanja od modela i povoljnije statističke kriterijume u odnosu na model zasnovan na punom faktorijelnim planu. Boks-Benken-ov plan, koji zahteva manji broj eksperimenata, može da se preporuči za optimizaciju proizvodnje biodizela u ultrazvučnom reaktoru.

Ključne reči: Biodizel, Boks-Benken-ov plan, centralni kompozitni plan, pun faktorijelni plan, metodologija površine odziva, ultazvučna transesterifikacija.

Naučni rad

Rad primljen: 01. 11. 2018.

Rad prihvaćen: 09. 01. 2019.

Rad je dostupan na sajtu: www.idk.org.rs/casopis

(c) 2019 Authors. Published by Engineering Society for Corrosion. This article is an open access article distributed under the terms and conditions of the Creative Commons Attribution 4.0 International license (https://creativecommons.org/licenses/by/4.0/) 